\title{
Association of Household Food Security with Anaemia among Children of a Selected Rural Area of Bangladesh
}

\author{
Khan $\mathrm{MNI}^{1}$, Jahan $\mathrm{N}^{2}$, Wahab $\mathrm{MA}^{3}$, Zafreen $\mathrm{F}^{4}$
}

DOI: https://doi.org/10.3329/jafmc.v14i2.45892

\begin{abstract}
Introduction: Food insecurity refers to a household's having "limited or uncertain availability of food, or limited or uncertain ability to acquire acceptable foods in socially acceptable ways". Iron deficiency and iron deficiency anaemia, are the most prevalent nutritional deficiencies worldwide and related to household food insecurity.
\end{abstract}

Objectives: To find out the association between household food security and anaemia in children of a selected rural area of Bangladesh.

Materials and Methods: This descriptive cross-sectional study was conducted among children ranging age from 12 to 60 months during the period ofJanuary 2009 to June 2009in Chandpur district. Mothers of the children were the respondents. A total of 192 children selected by simple random sampling were included in the study. Data were collected by face-to-face interview of the respondents and by estimation of haemoglobin of the children.

Results: The mean age of the children was $34.5 \pm 16.8$ months. Male children were more than the female children with male to female ratio being 3:2. The average monthly family income was taka 7500 . More than $60 \%$ of the mother had secondary level education. Farming was the prime occupation (36.4\%) of the father followed by business (25.5\%) and service (22.4\%). About $36 \%$ of the household did not have food security and nearly $45 \%$ of the children wereanaemic $(\mathrm{Hb}<11 \mathrm{~g} / \mathrm{dl})$. About two-thirds (65.2\%) children with household food insecurity was anaemic $(\mathrm{Hb} 11 \mathrm{~g} / \mathrm{dl})$. Estimation of odds ratio demonstrates that food insecured children were nearly 3 times as likely to develop anaemia as the children having household food security. The present study revealed a significant association $(P<0.001)$ between household food security and anaemia in children. Household food security was not influenced by age and gender of the children. Low family income and mother' illiteracy was significantly associated with household food insecurity.

Conclusion: The present study revealed a significant association between household food insecurity and anaemia in children. Household food security was not influenced by age and gender of the children. However, low family income and mothers' illiteracy play significant role in household food security.

Key-words: Food security, Haemoglobin, Anaemia, Children.

\section{Introduction}

Households living in poverty face significant constraints on their income that may result in food insecurity. Food insecurity refers to households having "limited or uncertain availability of food, or limited or uncertain ability to acquire acceptable foods in socially acceptable ways," as a result of inadequate financial resources ${ }^{1}$. Iron deficiency and iron deficiency anaemia, are the most commonly prevalent nutritional deficiencies worldwide ${ }^{2,3}$. A recent methodological advance in measurement opens the way to more detailed exploration of these issues, permitting clearer evaluation of the determinants and outcomes of child-level food insecurity ${ }^{4}$. Recently, a child food security scale has been developed using the childspecific items from the 18-item 'US Food Security Survey Module'. This scale permits more-accurate calculation of the prevalence of the children's lack of access to food which is sufficient for an active and healthy life.

Developing agencies often defined household food security as adequate access to food at all time, throughout the year and from year to year as a guiding principle for designing interventions in rural areas. At the international conference on nutrition (ICN) held in Rome in 1992, food security was defined as 'Limited or uncertain availability of nutritionally adequate and safe foods or limited or uncertain ability to acquire acceptable foods in socially acceptable ways ${ }^{5}$.

In the developing world including Bangladesh, a large body of research has demonstrated how dietary supplementation improves iron stores leading to improved developmental and cognitive outcomes in children, ${ }^{6,7}$. Dietary intake data have oftenbeen compared with measures of food sufficiency or food security as a means to validate this measures ${ }^{9,10}$ but there has been little evaluation of the interrelationships between status of food security measures and individual's dietary intake pattern.

Over 800 million people or $13 \%$ are chronically undernourished in a world that can produce sufficient food for everyone and some 200 million children aged under five suffered from protein and energy deficiencies ${ }^{11}$. In 1996, countries at the World Food Summit agreed that "Food security exists when all people, at all times, have physical and economic access to sufficient, safe and

1. Col Md Nazrul Islam Khan, PBGMS, MBBS, MPH, Deputy Director General, Border Guard Hospital, Dhaka (E-mail: nazrulsidrat@ gmail.com) 2. Dr Nasim Jahan, MBBS, Consultant (Paediatrics \& Neonatology), Asgar Ali Hospital, Gendaria, Dhaka 3. Lt Col Md Abdul Wahab, MBBS, MD, Associate Professor of Biochemistry, AFMC, Dhaka 4. Dr Farzana Zafreen, MBBS, MPH, Associate Professor and Head, Department of Community Medicine, Medical College for Women \& Hospital, Uttara, Dhaka. 
nutritious food to meet their dietary needs and food preferences for an active and healthy lifestyle"11. Although household food insecurity has an association with socioeconomic status, $50 \%$ of food-insecure households have incomes above the poverty line ${ }^{12}$. Household food insecurity has been associated with decreased household food supplies ${ }^{13}$. However, the relations among household food security, food supplies, and children's food intakes are not known. The present study aimed to evaluate the association between household food security status and anaemia among under-five children.

\section{Materials and Methods}

This descriptive cross-sectional study was conducted in a selected rural area, Kalacho Union, Hajiganj Upazila under Chandpur district between January 2009 to June 2009 to find out the association between household food security and anaemia in children. Apparently healthy children of age ranging from 12 to 60 months were the study population and mothers of the children were the respondents. Apparently diseased children were excluded from the study. A total of 192 such children were included in the study by simple random sampling. Data were collected by face-toface interview of the respondents through 18 item questionnaire to assess household food security; each question was assigned a score. Thus 18 questionnaires together produced a maximum score of 51 . A child who got $>15$ score was considered as having food insecured and score of 15 or $<15$ as food secured household. Haemoglobin level in children was estimated by Shahli's method by a qualified laboratory technician. Level of haemoglobin<11 gm/ $\mathrm{dl}$ was defined as anaemia. Data were processed and analyzed using SPSS 17.0 for windows. All results are expressed as mean \pm SD or in frequencies as applicable and Chi-square test was performed to see the association between anaemia and sociodemographic characteristics with food security and $p$-value $<0.05$ was considered significant.

\section{Results}

Apparently healthy 192 children under five years were included in the study. Majority $41.1 \%$ of children were in the age group between $37-60$ months having mean age of $34.5 \pm 16.8$ months. Children were mostly male $58 \%$ with male to female ratio $3: 2$. The average monthly family income was Taka 7500 and majority $57.8 \%$ had monthly income above 5000 BDT. About $60.4 \%$ of the mothers were educated up to secondary level and majority $36.4 \%$ of the fathers were farmer (Table-I). About $64.1 \%$ households were food secure and $44.8 \%$ children were anaemic (Table-II). Around two thirds $(65.2 \%)$ of children with household food insecurity was anaemic $(\mathrm{Hb}<11 \mathrm{gm} / \mathrm{dl})$ as opposed to just one-third $(33.3 \%)$ of those children who had household food security $(p<0.001)$. Age and sex were not determinants of household food security $(p=$ 0.211). Most (84.1\%) of the food insecured children belonged to low-income family (taka 5000 or below) compared to $18.7 \%$ of the food secured children $(p<0.001)$. About $19 \%$ of the mothers of food in secured children were illiterate in comparison to only $1.6 \%$ of the mothers of food secured children. Illiteracy was found to be significantly associated with household food insecurity $(p<0.001)$ (Table-III). Over two-third $(67.7 \%)$ of the children used to take green/red leafy vegetables, $12,5 \%$ took iron rich fruits at least once per day, over one-third $(36.5 \%)$ of the children took fish at least once per day and $6.8 \%$ children have had egg once per day.On the other hand, majority of the children did not take liver $(93.8 \%)$, beef $(74.0 \%)$, mutton $(85.4 \%)$ or chicken $(48.4)$ even once in a month (Table-IV).

Table-I: Socio-demographic characteristics of the children's family $(n=192)$

\begin{tabular}{|c|c|c|c|}
\hline & Variables & Frequency & Percentage \\
\hline \multirow{4}{*}{ Age in months } & $12-18$ & 59 & 30.7 \\
\hline & $19-36$ & 54 & 28.2 \\
\hline & $37-60$ & 79 & 41.1 \\
\hline & \multicolumn{3}{|c|}{ Mean age $34.5 \pm 16.8$ months } \\
\hline \multirow[b]{2}{*}{ Sex } & Male & 111 & 58 \\
\hline & Female & 81 & 42 \\
\hline \multirow{2}{*}{\begin{tabular}{|l} 
Monthly Family \\
Income(Taka)
\end{tabular}} & $<5000$ & 81 & 42.2 \\
\hline & $>5000$ & 111 & 57.8 \\
\hline \multirow{4}{*}{$\begin{array}{l}\text { Maternal } \\
\text { Education }\end{array}$} & Illiterate & 15 & 7.8 \\
\hline & \begin{tabular}{|l} 
Primary \\
\end{tabular} & 35 & 18.2 \\
\hline & Secondary & 116 & 60.4 \\
\hline & Higher secondary and above & 26 & 13.6 \\
\hline \multirow{7}{*}{$\begin{array}{l}\text { Father's } \\
\text { Occupation }\end{array}$} & Farming & 70 & 36.4 \\
\hline & Business & 49 & 25.5 \\
\hline & Service & 43 & 22.4 \\
\hline & Rikshaw-puller & 8 & 4.2 \\
\hline & Day labourer & 5 & 2.6 \\
\hline & Unemployed & 11 & 5.7 \\
\hline & Others & 6 & 3.2 \\
\hline
\end{tabular}

Table-Il: Household food security and haemoglobin level of the children $(n=192)$

\begin{tabular}{|l|l|c|c|}
\hline \multicolumn{2}{|c|}{ Variables } & Frequency & Percentage \\
\hline $\begin{array}{l}\text { State of household } \\
\text { food security }\end{array}$ & Insecured (score >15) & 69 & 35.9 \\
\cline { 2 - 4 } & Secured (score $\leq 15)$ & 123 & 64.1 \\
\hline \multirow{3}{*}{$\begin{array}{l}\text { Level of hemoglobin } \\
\text { (gm/dl) }\end{array}$} & $<6$ & 05 & 2.6 \\
\cline { 2 - 4 } & $6-9$ & 26 & 13.5 \\
\cline { 2 - 4 } & $9-11$ & 55 & 28.7 \\
\cline { 2 - 4 } & $\geq 11$ & 106 & 55.2 \\
\hline
\end{tabular}

Table-III: Association between food security with demographic characteristics and hemoglobin level of children $(n=192)$

\begin{tabular}{|l|l|r|r|l|}
\hline \multicolumn{2}{|c|}{} & \multicolumn{2}{|c|}{ Household food security } & \multirow{2}{*}{ Demographic characteristics } \\
\cline { 3 - 4 } \multicolumn{2}{|c|}{$\begin{array}{c}\text { In secured } \\
(n=69)\end{array}$} & $\begin{array}{r}\text { Secured } \\
(n=123)\end{array}$ & \\
\hline \multirow{3}{*}{ Age (in months) } & $12-18$ & $22(31.9)$ & $37(30.1)$ & \multirow{2}{*}{$>0.05$} \\
\cline { 2 - 4 } & $19-36$ & $21(30.4)$ & $33(26.8)$ & \\
\cline { 2 - 4 } & $37-60$ & $26(37.7)$ & $53(43.1)$ & \\
\hline \multirow{2}{*}{ Sex } & Male & $44(63.8)$ & $67(54.5)$ & \multirow{2}{*}{$>0.05$} \\
\cline { 2 - 4 } & Female & $25(36.8)$ & $56(45.5)$ & \\
\hline \multirow{2}{*}{ Family income } & $\leq 5000$ Taka & $58(84.1)$ & $23(18.7)$ & \multirow{2}{*}{$<0.001$} \\
\cline { 2 - 4 } $\begin{array}{l}\text { Mothers' } \\
\text { educations status }\end{array}$ & Illiterate & $11(15.9)$ & $100(81.3)$ & \\
\cline { 2 - 4 } & Primary & $23(33.8)$ & $2(1.6)$ & \\
\cline { 2 - 4 } & $\begin{array}{l}\text { Secondary } \\
\text { and higher }\end{array}$ & $33(47.8)$ & $109(88.6)$ & \\
\hline \multirow{2}{*}{ Hemoglobin (gm/dl) } & $<11$ (Anaemic) & $45(65.2 \%)$ & $41(33.3 \%)$ & \multirow{2}{*}{$<0.001$} \\
\cline { 2 - 4 } & $\geq 11$ (normal) & $24(34.8 \%)$ & $82(66.7 \%)$ & \\
\hline
\end{tabular}

Data were analyzed using Chi-square $\left(X^{2}\right)$ 
Table-IV: Iron containing food intake pattern of children $(n=192)$.

\begin{tabular}{|l|r|r|r|r|}
\hline \multirow{2}{*}{\multicolumn{1}{|c|}{ Food Item }} & \multicolumn{4}{|c|}{ Food intake pattern } \\
\cline { 2 - 5 } & $\begin{array}{c}\text { Never } \\
\text { or<once I } \\
\text { month }\end{array}$ & $\begin{array}{c}\text { Once per } \\
\text { month }\end{array}$ & $\begin{array}{c}\text { Once per } \\
\text { week }\end{array}$ & $\begin{array}{r}\text { Once per } \\
\text { day }\end{array}$ \\
\hline $\begin{array}{l}\text { Green/red leafy } \\
\text { vegetables or green } \\
\text { banana }\end{array}$ & $3(1.6)$ & $5(2.6)$ & $54(18.1)$ & $130(67.7)$ \\
\hline $\begin{array}{l}\text { Banana, guava \& other } \\
\text { iron enriched food }\end{array}$ & $18(9.4)$ & $10(5.2)$ & $140(72.9)$ & $24(12.5)$ \\
\hline Liver & $180(93.8)$ & $12(6.3)$ & $0(0.0)$ & $0(0.0)$ \\
\hline Fish & $23(12.0)$ & $1(0.5)$ & $98(51.0)$ & $70(36.5)$ \\
\hline Egg & $66(34.4)$ & $10(5.2)$ & $103(53.6)$ & $13(6.8)$ \\
\hline Beef & $142(74.0)$ & $44(22.9)$ & $6(3.1)$ & $0(0.0)$ \\
\hline Mutton & $164(85.4)$ & $27(14.1)$ & $1(0.5)$ & $0(0.0)$ \\
\hline Chicken & $93(48.4)$ & $84(43.8)$ & $15(7.8)$ & $0(0.0)$ \\
\hline
\end{tabular}

\section{Discussion}

The present study revealed that about two thirds $(65.2 \%)$ of children with household food insecurity was anaemic $(\mathrm{Hb}<11$ $\mathrm{gm} / \mathrm{dl})$, as opposed to children with household food security $(33.3 \%)$ and the risk of developing anaemia, was nearly 3 folds in food insecured children than that in food secured children. Previous researches on the relationships between food insecurity and iron deficiency and other micronutrient deficiencies rely primarily on dietary reports not validated by objective laboratory measures. Kaiser et $\mathrm{al}^{14}$ in his study among low-income Mexican-American preschool-aged children found child hunger was associated with a diet less likely to meet Food Guide Pyramid recommendation. Research during the mid-1970s linked rising cost of foods rich in micronutrients (vegetables, meats) to increase in prevalence of iron deficiency anaemia among low-income school-aged children ${ }^{15}$. These findings are inconsistent with the findings of the present study.

While the relationship between food insecurity reported by caregivers and objective indicators of nutrient deficiency measured in children is not clearly delineated, there is accumulating evidence of a negative association of food insecurity with anumber of more distal health and developmental outcomes. Recent research, principally focusing on schoolaged children, has described the relationship between household food insecurity and children's reported health status ${ }^{16}$ and cognitive, academic ${ }^{17}$ and behavioural development ${ }^{18,19}$. Exact mechanisms by which child-level food insecurity, in the absence of severe protein-energy malnutrition, influences the development of infants and toddlers are unknown. However, it is speculated that iron deficiency anaemia may be one such physiologic mechanism between child food insecurity and developmental consequences since it is a known risk factor for adverse cognitive and behavioural outcomes ${ }^{8-11}$. Iron deficiency anaemia may develop for several reasons: 1) food deprivation; 2) poor food choices; 3) preceding state of poor health resulting in inability to ingest or absorb iron-rich foods.
All these factors are the consequences of household food insecurity.

US Department of Agriculture research ${ }^{20}$ has shown that participation in the Special Supplemental Nutrition Program for Women, Infants, and Children (WIC) program significantly improves children's intakes of iron, folate, and vitamin B-6. Participation of WIC also improves the Healthy Eating Index scores for the household. In a retrospective cross-sectional and longitudinal analysis by Kahn et $\mathrm{al}^{15}$, anaemia was found to emerge and persist in children participating in the program. The data pertaining to iron-containing food intake pattern of the children revealed that two-third of the children took green/ red leafy vegetables regularly, although none of the children had liver, beef, mutton and chicken even once in a month. Green/red leafy vegetables are although rich in iron, their bioavailability is poor. The bioavailability of iron-rich animal food is much better than the iron-rich plant food. Therefore, to prevent anaemia, making iron-containing food available is not enough; rather quality of iron-containing food must also be kept in mind.

Despite the proven benefits of WIC and FSP, the residual nutritional risk may persist even in recipient families because the programs are designed to supplement the food budget rather than support the food budget in total. Since the late 1990s, the housing and utility costs have risen faster than food costs. The programs designed to be supplemental now may constitute the major source of families' nutrition. Skalicky ${ }^{21}$ and his associates in 2006 showed an association between child-level food insecurity and iron deficiency anaemia, a clinically important health indicator with a known negative cognitive-behavioural and health consequences. Various publications ${ }^{22,23}$ have indicated that food assistance and income maintenance programs can buffer low-income families from food insecurity.

\section{Conclusion}

The present study revealed a significant association between household food insecurity and anaemia in children. Household food security was not influenced by age and gender of the children. However, low family income and mothers' illiteracy play significant role in household food security. Policymakers therefore need to consider programs that empower people to solve their own problem of food insecurity and provide food assistance to families with young children.

\section{References}

1. Bickel G' Nord M' Price C Hamilton W, cook J. Guide to measuring household food security. Arexandria, VA US Department of Agriculture, Food and Nutrition Service, 2000.

2. Looker AC, Dallman PR, Carroll MD et al. Prevalence of iron deficiency in the United States. JAMA 1997; 277(12):973-6. 
3. Centers for Disease Control and Prevention. Recommendations to prevent and control iron deficiency in the United States Morb Mortal Wkly Rep 1998, 47:3.

4. Bangladesh Mission Food Security Strategy; for new Title II Development Assistance Programs; in the FY 2006 Review Cycle, Webpage food security strategy DAP 2006.2.

5. Alaimo K, Oslon CM, Frongillo EA et al. Food insufficiency, family income, and health in US. Preschool and school-aged children. Am J Public Health 2001; 91(5):781-6.

6. Life Sciences Research Organization. Core indicators of nutritional status for difficult to sample populations. J Nutr 1990; 120 (suppl):1559-600.

7. Ash DM, Tatala SR, FrongilloJr EA et al. Randomized efficacy trial of amicronutrient-forlified beverage in primary school children in Tanzania. Am J Ctin Nutr 2003; 77(4):891-8.

8. Pollit E, Saco-Pollitt C, Jahari A et al. Effects of an energy and micronutrient supplement on mental development and behavior under natural conditions in undernourished children in Indonesia. Eur J Clin Nutr 2000; 54 (Suppl 2):S80-S90.

9. Benton D. Vitamin-mineral supplement and intelligence Proc Nutr Soc 1992; 51(3):295-302.

10. Frongillo EA Validation of measures of food insecurity and hunger. The Journal of Nutrition 1999; 129(2):506S-509S.

11. Rose D, Oliveira V. Validation of a self-reported measure of household food insufficiency with nutrient intake data (Technical Bulletin No. 1863). Washington, DC: US Department of Agriculture. Economic Research Service. 1997.

12. Disabled World Disability News. Food Security: Definition \& General Information. Available at (Accessed on 6/15/2009).

13. Food security strategy. Australian Government. AUSAID; May 2004. Web address: www.ausaid.gov.au/publications. Accessed on $6 / 15 / 2009$.

14. Kaiser LL, Melgar-Quinonez HR, Lamp CL et al. Food security and nutritional outcomes of preschool age Mexican-American children. J Am Diet Assoc 2002; 102(7):924-9.
15. Kahn JL, Binns HJ, Chen Tet al.Persistence and emergence of anemia in children during participation in the special supplemental nutrition program for women, infants and children. Arch Pediatr Adolesc Medd 2002; 156(10):1028-32.

16. Nord M, Andrews M, Carlson S. Household food security in the United States, 2002 Food Assistance and Nutrition Research Report No.(FANRR35), October 2003:58.

17. Perez-Escamtlia R, Ferris AM, Drake L etal. Food stamps are associated with food security and dietary intake of innercity preschoolers from Hartfood, Connecticut. J Nutr 2000; 130(11):2711-7.

18. Rose D, Habicht JP, Devaney B. Household participation in the Food stamp and WIC programs increases nutrient intakes of preschool children J Nutr 1998; 128(3):548-55.

19. Wiecha JL, Palombo R. Multiple Program participation: Comparison of nutriotion and food Assistance program Benefits with Food Costs in Boston, Massachusetts Am J Public Health 1989; 79(5):591-4.

20. Meyers A, Cutts D, Frank DAet al. Subsidized housing and children's nutritional status: data from a multisite study. Arch Pediatr Adolesc Med 2005; 159:155-6.

21. Skalicky A, Meyers AF, Adams WG et al. Child food insecurity and iron deficiency anaemia in low income infants and toddlers. Maternal and Child health journal 2006; available at: http://www.medscape. com. Accessed on 6/15/2009.

22. Troiano R, Flegal K, Kuczmarski $R$ et al. Overweight prevalence and trends for children and adolescents: the National Health and Nutrion Examination Surveys, 1963 to 1991. Arch Pediatr Adolesc Med 1995; 149:85-91.

23. Black MM, Cutts DD, Frank DA et al. Children's Sentinel Nutritional Assessment Programme Study Group, Special supplemental nutritional programme for women infants and children participation and infant's growth and health: a multisite surveillance study. Paediatrics 2004; 114(1):169-76. 